Savage, Jordan (2020) 'True Grit: Dirt, Subjectivity and the Female Body in Contemporary Westerns.' Zeitschrift für Anglistik und Amerikanistik, 68 (1). 53 - 66. https://doi.org/10.1515/zaa-2020-0006

\title{
True Grit: Dirt, Subjectivity and the Female Body in Contemporary Westerns.
}

\author{
"I wanna build me a wall so high nothing can burn it down, \\ Right here on my own piece of dirty ground" \\ - Bruce Springsteen, "Souls of the Departed."
}

"Oh the poor old dirt farmer, he can't grow no corn, And now where's the money to pay off his loan?"

- Levon Helm, "Poor Old Dirt Farmer."

Westerns as a genre rely on the metaphorical and aesthetic potential of dirt. "True Grit" (Pontis 1968) expresses the core values of the Western character; "Bad Dirt" (Proulx 2004) is the key barrier to aspiration in Western agriculture. Part of this potential stems from the fact that in the Western idiom, "dirt" and "land" can be used almost interchangeably. The polyvalence of dirt as in land, and dirt as in pollutant, underpins most, if not all, uses of the word "dirt" in Western texts across media. Dirt as pollutant, however, has complex moral connotations. For Bruce Springsteen in "Souls of the Departed," dirt is a moral good. He builds on the connotations of poverty implicit in a dirty aesthetic, colloquially "dirt poor," to use the "dirty ground" a site of resistance to the enclosure acts of "the land of King Dollar". In My Ántonia, on the other hand, Mrs Shimerda's dirty home to implies her inferiority to Emmeline Burden. The dirt is mapped onto her character, her femininity, and the immigrant woman's potential to found a happy and embedded American family (Cather 2008). 
This article considers the significance of dirt to three Western texts: Lonesome Land, (Bower 2015) Mudbound, (Rees 2017) and Brokeback Mountain. Taking B.M. Bower's 1912 Western Romance as a model, it will be argued that the dirt aesthetic is crucial to how Westerns construct the myth of the American character as both "true," and "grit": honest and authentic, and fundamentally tough. The female protagonist of Lonesome Land allows us to explore how the dirt that valorises American masculinity takes on different connotations when it is applied to the female body. This analysis carries over to Mudbound, where the representation of the dirty white female body generates pathos by creating an image of a fallen angel; in both Lonesome Land and Mudbound, dirt connotes sexual impurity, and so the dirty female body is a sexualised body, attracting a different kind of gaze to the pristine body. Mudbound was adapted by writer-director Dee Rees, and Screenwriter Virgil Williams from a novel by Hillary Jordan (Jordan 2008). The analysis herein focuses on the film alone, as the subject of enquiry is the iconography of the female body on screen. Jordan's novel is generically uncomplicated as an intervention into Southern literature, from a liberal political perspective, with a focus on reconciling Southern race narratives. The film, however, merits inclusion in a study of contemporary Westerns because of its construction of the dirty, white, female body. The argument in this paper is that constructing a heroic rural poor through representations of the dirty body, has an inherent contact with frontier, and therefore Western, iconography. The film generates empathy with Laura McAllan (Carey Mulligan), by invoking the Western trope of American self-making through contact with the land. The final part of this investigation returns to the ambiguity of dirt: that it can be read as an essential part of the American land, or as polluting waste matter. The association between dirt and queerness in Annie Proulx's 1999 short story “Brokeback Mountain” (Proulx 1999) is read in contrast to the representation of dirt in Ang Lee's 2005 screen adaptation (Lee 2005). Lee's film follows the template established by B.M. Bower and Dee Rees much more closely, 
having the association of dirt adhere to the character of Alma Beers (Michelle Williams). In the short story, however, the dirt expresses the queer subjectivity of Ennis Del Mar (Heath Ledger). The overall argument presented here is that the more complicated and ambiguous dirt is permitted to be, the more imaginative and critical potential it has for the iconography of the contemporary Western.

In his introduction to the 2011 collection The Brokeback Book, William R. Handley offers a new definition of the Western, as any text that offers “...studies in gender difference within a nationalised landscape" (Handley 2011, 12). What this brings into view is that Westerns have always been concerned with gender, originally in their juxtaposition of the masculine hero, to the feminised landscape. Across the history of Western scholarship, the landscape as feminine ideal has been re-centred as a material integrated location (Healey 2019). In this analysis of B.M. Bower's Lonesome Land, the question of the ideal American character is brought into contact with the iconography of dirt, and its role in representing female subjectivity.

Lonesome Land is a generically uncomplicated Western Romance, which follows conventions to the letter - to the point that the Western archetype of chivalrous masculinity is a character simply named "Kent," who is set up in opposition to a degenerate Easterner, recently arrived in Montana, who bears the misleading name "Manley." Real Western masculinity, we are to infer, does not need to announce itself. The biggest innovation that Lonesome Land makes is the substitution of a female protagonist for a male one. Beyond that, the formula is simple: an easterner arrives in the symbolically-named Western town of Hope, Montana, full of pre-conceived notions about the West as a picturesque nature cure. She anticipates "bearskin rugs, and antlers on the walls, and big fireplaces!" Instead, she finds Montana "dusty": this adjective is applied to both interiors and exteriors as soon as she disembarks from the train (Bower 2015, 9). The Easterner does not understand the manners 
of the people to begin with, but after having to rely on them in times of rural hardship, in which they discover their own inner strength by bringing a wild patch of land under control, they become an integrated part of the Western community. This is the penny-dreadful West, and it adheres precisely to the mega-myth of the frontier set out in Frederick Jackson Turner's frontier thesis, in which the European is transmuted by the land into the American (Turner 1920). They get dirty in the process, but the dirt is honourable: it is the dirt of transforming the "wilderness" of Turtle Island, into "America" - the white European name for the U.S.A. What Turner is describing here, is, explicitly, the process of colonialism at its rural edges. The "rugged" nature of the American character, that belongs in its cultural lexicon of dirt and grit, is formed by the co-option and eradication of indigenous land practices.

For Val Peyson (later Fleetwood), the process of becoming both dirty, and properly American, is intrinsically linked to her autonomy and sexuality as a woman. When she first arrives in Montana, we see her as "a slim young woman," with "yellow-brown hair and yellow-brown eyes to match" (Bower 2015, 8): youthful, contained, co-ordinated even at the level of her (fair) natural colouring. She has a "violin box and two trunks," (Bower 2015, 9) causing ageing busy-body Polycarp to exclaim, "By granny - two trunks, to one woman!" and exclaim that if she takes all of this baggage into Manley Fleetwood's "shack," she herself will have to spend her days outside (Bower 2015, 18). The big battle with the elements comes, for Val, when she is left at home during a sudden prairie fire. Stumbling fortuitously upon her in her vain efforts to defend her home, Kent Burnett tells her not to bother: "[y]ou'll spoil your complexion... and that's about all you will do..." (Bower 2015, 73). Val is determined, however, and she and Kent together protect the Fleetwood home from the ravages of the fire although she does, eventually, pass out from the effort and the heat. This gives Kent the opportunity to look at her again. Bower writes: 
Her hair was a tangled mass of gold upon her head, and spilled over his arm. He carefully picked a flake or two of charred grass from the locks on her temples, and discovered how fine and soft was the hair. He lifted the grimy neckerchief from her eyes and looked down at her face, smoke-soiled and reddened from the heat... His gaze travelled on down her slim figure to her ringed fingers lying loosely in her lap, a long, dry-looking blister upon one hand near the thumb; down to her slippers, showing beneath her scorched skirt. And he drew another long breath. He did not know why, but he had a strange, fleeting sense of possession, and it startled him into action. (Bower $2015,79)$

The dirt of doing battle with the prairie changes Val, presented to us via Kent's interpretation throughout the novel, in two key ways. Firstly, having survived the prairie fire, Val becomes a more integrated part of society in Hope, building new intimacies with her neighbours. Her appearance has also changed: she has taken on the physical dirt of the environment. The dirt on the formerly pristine Eastern body gives the reader, via Kent, the opportunity to look at her again - and to look at her with a newly sexualised gaze. Idealised femininity - the femininity of white gentility - is never dirty. As Phyllis Palmer argues, the upper- or middle-class wife maintains all the nurturing characteristics of the mother, ideally acted out towards her husband as well as her children - but produces children without showing any sign of the dishevelment of sex; she also inhabits a clean and orderly home, without trace of the process of having to remove dirt. Palmer writes that, "[1]adies looked like, or were perceived as, delicate, pure creatures, almost too pure to be sullied by the exigencies of living" (Palmer 1989, 146) - something that Kent's caution about Val's complexion picks up. She reminds us, too, that the origin of the derogatory term "slut" for a sexually promiscuous woman is in "slattern", originally meaning "kitchen maid." Eventually, the implications of working-class identity and comparative scruffiness, or dirtiness, become associated with sex. For Lonesome 
Land, this is a perfect combination: it is, after all, a Romance. In terms of the current argument however, what is significant in Bower's text is that, yes, dirt allows her to draw out Val's sexuality - something that is certainly replicated in Mudbound. Moreover, the dirty female body is used to dramatize the male gaze. We see Kent look at Val's head, hand, body, foot, and finally skirt: dirt sticking to the idealised female body is anomalous, and it is a reason to look, and look closely.

Through tracking Val's integration into Montana society and its impact on her pristine East-Coast appearance, we can see the making of an American hero. We also see the application of dirt to an ideal feminine body as a reason to look closely at that body. Kent's regard is both proprietary, and sexualised: he recognises the dirty woman as attractive, and also as compatible with, or belonging to, his own American character. The reader's gaze, whilst participating in the sexual frisson that drives the narrative, is also sympathetic: Val has worked hard, she is exhausted, and she has given something of herself in surrendering her immaculate dress and coiffeur. This is the symbolic death of the European character, just before her American rebirth, and it is a moment in which she is completely vulnerable, and has, through her hard work, become worthy of our sympathy and respect.

Some theoretical triangulation is necessary to get exactly what is happening here in view - and that same triangulation can be used to read Laura McAllan's dirty white body in Mudbound. Val is white, and this is essential to her position as embodying Turner's vision of the American. She is also middle-class, which means that she is an ideal woman, but also, initially, unfit to be properly American: full participation in this national identity requires the sloughing-off of class allegiance to become an integrated part of what Winfried Fluck characterises, in constitutional terms, as "the people" (Fluck 2010, 72). Finally, significantly, she is female: thus, the priority in framing her dirty body is not to emphasise her heroic 
qualities: this heroism is a by-product of setting up the sexualised attention to her body that is necessary to make the romance narrative commercially viable.

Each of these three aspects holds true for Laura McAllan, too. However, as Mudbound was released generations later, in 2019, the focus on the American heroism of Laura's character is sublimated: characters like Val, or like Bob Starret in Shane (Stevens 1953), or Linus Rawlings in How The West Was Won (Ford et al, 1962), have taught us that the figure of a dirty white face in a rural American setting, is heroic. Subsequently, generations of Western scholarship have shown that this formulation of "American" heroism is fundamentally a white supremacist one. ${ }^{1}$ Nevertheless, sociologist Kate Cairns argues that this construction of white rurality as maintaining contact with frontier identity continues into the twenty-first century. She asserts that, "rurality is often perceived as a space of whiteness, rooted in legacies of the British countryside that conjure images of blond-haired children playing innocently in open fields. This association takes on particular significance in the Canadian context, where it is bolstered by frontier narratives of rugged male settlers traversing Canada's harsh landscape" (Cairns, 626). Rural Canadian self-image among young white people, she finds, is actively informed by frontier mythology. In a Hollywood film with an agenda when it comes to talking about American national identity (Piacento, 2014), this connection is even more pronounced.

Both Val Peyton and Laura McAllan are taken out of middle-class contexts and exposed to dirt thanks to decisions made by men. Where Val actively engages in the processes of working the land, and "gets her hands dirty" in order to earn her heroic American status, Laura does no such thing. The domestic "angelic wife" is transported onto the farm, where she becomes physically dirty, by unlucky circumstance (Palmer 1989, 144).

\footnotetext{
${ }^{1}$ See, for a limited example: The Return of the Vanishing American (Fiedler, 1968) Invisible Natives: Myth and Identity in the American Western (Prats, 2002), Killing the Indian Maiden: Images of Native American Women in Film (Marubbio, 2006); Myth of the Western: New Perspectives on Hollywood's Frontier Narrative (Carter, 2014).
} 
She takes no part, however, in rural work; after she leaves suburbia, we no longer see her preparing food on-screen; she employs a black woman, her tenant Florence (Mary J. Blige), to care for her children. Writing specifically about classed interactions with dirt of the American period in which Mudbound is set, that of the Second World War, Phyllis Palmer writes that, "[t]he United States received the ethos of female fragility from Europe, especially England, and added its own unique system of gender differentiation developed in the institution of black slavery" (Palmer 1989, 146). This builds on the underlying principle of her book, that, "sex, dirt, housework and badness in women are linked in Western unconsiousnesses and that white middle-class women are sought to transcend these associations by demonstrating their sexual purity and their pristine domesticity." (Palmer 1989, 138). The spectre of slavery is a constant presence in Mudbound, and it is brought into the McAllan house by the employment of Florence as nurse to Laura and Henry's (Jason Clarke) children. This dramatizes the extent to which Laura is fighting to keep her pristine, Europeanised fragility: she brings a lower-class woman into her home, to get between her and at least the dangerous aspects of the dirt (she employs Florence after her children contract whooping cough).

Laura is a white woman who, in her own words, "loved domestic life"; was "civilised" enough actually to play the piano, and who believed, with the best of her kind that she was "put on earth" to "yield" to her husband. She is forced to live on a very muddy farm, with people of a much lower social class. She tells us, in a voice-over that is very literal, and so denies the audience much co-constructive participation in the text, that "Saturday was my favourite day of the week. It was the only time that I felt really clean." As she says this, the film shows her naked in the bathtub, sheets hung as ineffectual screens to protect her modesty. Her father-in-law (Pappy McAllan, played by Jonathan Banks), who is a drunk, and a Klansman, and therefore not permitted the subjectivity of his own voiceover in this liberal 
text, walks deliberately past her and watches her bathe. Where the male gaze on Val Peyton's dirty body is part and parcel of the novel's liberation narrative, as her sexual agency is key to the resolution of the story, Laura has been keen on demonstrating her sexual purity from the beginning of the film. She is pitiable because she has no agency: she is doing everything she should do to preserve her divine status, and yet she still has to appear like an implicitly morally degenerate lower-class woman.

This is a narrative trick. Laura McAllan is not, actually, lower-class at all: she is just dirty. She is living in a property that her husband owns, and all the neighbours, including Carl and Vera Atwood and Florence and Hap Jackson, are their tenants. Their residence on the farm is temporary, brought about by Henry's misfortune, represented as incompetence: he was cheated out of the deposit he paid on a large rental house nearby, and so the family move to a tenant's residence on the property, whilst they await another rental opportunity. Mudbound constantly portrays Carey Mulligan's beautiful white body as rain-sodden or muddy. This is reinforced by having her constantly talk about the mud - the first thing she says in the film is, "[w]hen I think of the farm, I think of mud" - and fetishizing her bathing. Eventually, we sympathise with her sleeping with her brother-in-law, Jamie (Garrett Hedlund), in part because he was the one who built her a screened-off shower, to make bathing easier and to protect her modesty: he is an appropriate partner for the vulnerable white woman.

The reason for all this is to create a sense of parity between Laura McAllan's experiences, and those of her neighbour Florence. Florence Jackson is never, throughout the film, shown to be dirty - although at one point, she does behead a chicken, in the middle of a montage that shows the dirt of those around her. She is shot in warm colours, against Laura's greys, browns and greens. In addition to helping her family work their 200 acre plot of land, she works for Laura, performing all the dirty tasks that according to Palmer, are done by the 
servant in order to sustain class distinctions by keeping the white middle-class woman clean (Palmer 1989, 145-6). By implication, Florence and her family belong on the muddy farm in a way that the McAllans do not; it makes the white family dirty, but for the black family, it is an accommodating home. This could be read as disputing the McAllans' right to the property. Henry's first soliloquy opens up the pun between "land" and "dirt" to take in questions of ownership and value; according to this reading, the McAllans' presence on the farm may render them, as the white land-owning class, morally dirty. This reading is undermined by the representation of Laura's body. The dirt is repeatedly used to bring the audience onto Laura's side, without Laura having to do anything active to earn that sympathy. As a result, Laura is seen as having to temporarily endure what is actually unendurable. This unendurable dirt is simultaneously seen, by both the audience and the Jacksons themselves as an appropriate position for the black family to aspire to. In his first soliloquy, Hap Jackson (Rob Morgan) essentially explains that he would consider owning his 200 acre plot adequate reparation for slavery. According to Palmer, “'[d]irtiness' appears always in a constellation of the suspect qualities that, along with sexuality, immorality, laziness, and ignorance, justify social rankings of race, class and gender" (Palmer 1989, 140). This is reinforced in Mudbound apparently without the conscious intention of either novelist, or director. The drama of the dirt in this text is in the fact that Laura is demonstrably working against the odds to avoid dirtiness, but is too weak and fragile to succeed. Thus, social rankings of race and class come into play to help to protect her. Somehow, this hyper-attention to the needs of the bourgeoise white woman, who is incapable of defending herself against the dirt she encounters, is intended to imply social equality between Laura and Florence, who, after all, are both women in a difficult situation.

The third part of this analysis explores the potential for dirt as an expression of subjectivity, rather than objectification, in Brokeback Mountain. Taking in both Annie 
Proulx's 1999 short story and Ang Lee's 2005 screen adaptation, this part of the argument will demonstrate how in Proulx's short story, representations of dirt adhere to the character of Ennis Del Mar (Heath Ledger). In this context, dirt, effluvia, and by-products do not carry the same sense of moral or spiritual degradation that they do in the other texts considered here. In Ang Lee's film, however, the representation of dirt cleaves to the character of Alma Beers. As a result, dirt in the later text follows the model set up by Lonesome Land and Mudbound much more closely than Proulx's story does.

On Brokeback Mountain, Jack Twist (Jake Gyllenhaal) and Ennis Del Mar spend all of their time outside. They wash in tin cans beside a river. They spend their evenings enveloped in woodsmoke. They manhandle sheep, skin and cure deer, and shoot at predators, lying flat on the ground as they do so. They have anal sex on at least one occasion - more are implied - and they bloody one another's noses, bleeding on their clothes. Jack preserves those bloodied shirts for the rest of his life, and Ennis take over custodianship of them when his friend dies. These rural men are tied to the earth, and to one another, by the pallet of dirt that is established on the mountain in the summer of 1963.

Proulx reiterates the dirt of that summer on Brokeback Mountain whenever she describes intimate moments between Jack and Ennis. Most notably, on the day of their reunion four years after they parted on the mountain, Proulx describes them as follows:

The room stank of semen and smoke and sweat and whiskey, of old carpet and sour hay, saddle leather, shit and cheap soap. Ennis lay spread-eagled, spent and wet, breathing deep, still half tumescent, Jack blowing forceful cigarette clouds like whale spouts... (Proulx 1999, 297)

The metaphorical link between dirt and queer sex, especially sex between men, is not new at this point, and that construction of dirt and the unclean has been taken to heart by queer artists across media. In his 2009 article “'Baby, I am the garbage': James Schuyler's Taste for 
Waste," which contains the nucleus of his subsequent monograph, The Poetics of Waste: Queer Excess in Stein, Ashbery, Schuyler and Goldsmith, Christopher Schmidt articulates the link between dirt, and articulations of queer sexuality (Schmidt 2009). His analysis adds yet another valence to the already charged term, "dirty": that of the "dirty secret," the manifestation of an aesthetics of dirt, or in his terms waste, as a mechanism for articulating shame. Schmidt argues for a camp aesthetic (Schmidt 2009, 59), which may or may not be a useful mechanism for approaching Brokeback Mountain as a means of concretising the cultural conversation around waste and queer shame (Halberstam 2011). He posits that, for New York School poet James Schuyler, “camp is located at the imaginary switch-point between bodily waste and cultural waste, between the 'damaged' body (the queer body, the fat body) and the larger social body..." (Achmidt 2009, 59). Here, he demonstrates that a queer body is perceived socially as a broken body: a "waste product" in itself. The "switchpoint" between the "damaged body" and the "cultural body" is the point at which queerness as a site of shame is culturally enacted. The conclusion to Schmidt's article makes an association with Jonathan Swift's "excremental vision", and builds on this to tell us that, "Schuyler, like Swift, understands how waste can disrupt the decorum of the social sphere; as he learned in the Paris vespasienne, waste is a source of shame. But as a poet who would find his voice by embracing queer desires and ungainly excesses, Schuyler exemplifies the recuperative and playful ethos of camp waste management, showing us that waste matters" (Schmidt 2009, 71).

Two points here are useful in understanding the distinction between how dirt is employed in Annie Proulx's short story, and Ang Lee's film. Firstly, shame must necessarily be co-created, between the society that denotes certain behaviours as "shameful", and the individual, who lives with that shame. Lee's Brokeback Mountain subjectivises the social creation of the shame of homosexuality, by having Alma, who is a sympathetic character, 
embody the experience of queer sexuality as a pollutant in the nominally heterosexual home. Annie Proulx, on the other hand, does not manifest disgust around dirt, but rather shows us Ennis, inhabiting a world in which "waste matters." This is the second point to draw out from Schmidt: in accordance with Schmidt's construction of "camp waste management", Proulx dramatizes the pleasure available through dirt, and manifests dirt as necessary to a positive experience of the world.

In the short story, queer dirt carries over from the mountain and into the rest of Jack Twist and Ennis Del Mar's lives. Among the most persuasive readings of dirt in the story is Alex Hunt's analysis in his essay, "West of the Closet." He asserts that, "[w]hat Ennis finds comforting in his marriage to Alma - his penchant for anal intercourse aside - is 'the smell of old blood and milk and baby shit, and the sounds... of squalling and sucking and Alma's sleepy groans, all reassuring of fecundity of life to one who worked with livestock"' (Hunt 2011, 147).

This analysis does not see the smells of blood, old milk, and diapers in the Del Mar home as a mark of poverty and unpleasantness, something to respond to with disgust, but rather as the very thing that ties Ennis to his family: their dirt is essential to his understanding of their connection to the earth. Here, in the house that bares all the signs and scents of bodies, he is as lose to town - civilisation, mainstream, enclosed living - as he can stand to be. His horses, his daughters, and his lover are all, simply, "little darlin" to him (Proulx 1999, 295), and he looks for the same signs of animal participation in the world in his family, as he does in his horses and Jack.

Dirt for Ennis is essential to his understanding of life, and so it is tellingly absent from Proulx's construction of his struggle to understand death. The cohabitation in queer dirt that constitutes intimacy between Ennis and Jack is evoked in the culminating image of Jack and Ennis's relationship: 
The shirt seemed heavy until he saw there was another shirt inside it, the sleeves carefully worked down inside Jack's sleeves. It was his own plaid shirt, lost, he'd thought, long ago in some damn laundry, his dirty shirt, the pocket ripped, buttons missing, stolen by Jack and hidden here inside Jack's own shirt, the pair like two skins, one inside the other, two in one. He pressed his face into the fabric and breathed in slowly through his mouth and nose, hoping for the faintest smoke and mountain sage and salty sweet stink of Jack but there was no real scent, only the memory of it, the imagined power of Brokeback Mountain of which nothing was left but what he held in his hands. (Proulx 1999, 316)

The shirt is bloody because, when they were evicted from their new Eden on Brokeback Mountain by Aguirre, Ennis and Jack fought: the only language they had for the pain of separation (Carman 2011; Allen, 2007; Jones, 2011). The blood they draw remains on those shirts forever. For Jack, who creates the two-shirt monument, stowed in his hypersymbolised secret closet, the "tiny jog in the wall" that "made a slight hiding place," dirt stale, bloodied shirts that testify to the physicality of the mountain - is the right symbol to immortalise the most important relationship of his life. When Ennis takes the shirt from Jack's bedroom during his short, tense visit to Lightning Flat, he finds that the shirts are not, in fact, dirty enough: "there was no real scent, only the memory of it." Because Ennis could not commit to living fully in queer partnership with Jack, or possibly because Jack did commit more fully to living a queer life in an inhospitable society, at the end of the story, the joyful stench of queer dirt is gone from Ennis forever.

In Ang Lee's film, the dirty shirts in the pristine Pentecostal cleanliness of the Twist ranch are a vestigial trace of the queer dirt of the original text. Across the rest of the film, it is Alma's story in particular that makes use of dirt, contrasted against the uninhabitable cleanliness of Lureen Newsome's (later Twist; Anne Hathaway), middle-class home in 
Texas. The experience of living in dirt is the primary cinematic code that Lee employs to build empathy with Alma Beers. Like both Val Peyson, and Laura McAllan, we see the clean image of the ideal white woman become dirty over time. In the earlier days of their courtship, we see Ennis and Alma outdoor, playing in the snow, her face flushed pink but the cold; scrubbed clean in the funny, endearing wedding scene; and in soft, romantic lighting at the drive-in movie when she is pregnant with her first daughter, Alma Junior. More or less from that point on, Alma's life with Ennis is a descent into grime, with no attempt to preserve the sense that this dirt is "reassuring of fecundity and life's continuance."

The film therefore has to work to create characters for Alma and Lureen, Ennis and Jack's wives, who in the story, are the framework for establishing the claustrophobia of the closest and passing for straight. On film, the impact of attempted "passing" on the families of closeted queer characters must be explored, or the filmmakers risk sacrificing female characters to a male narrative. Thus, in Ang Lee's Brokeback Mountain, many of the same techniques that create pathos with Laura McAllan and Val Peyson are mapped onto Alma Beers - but the impact is that they develop her subjectivity, rather than objectifying her and reducing her simply to a female body. Soon after witnessing Alma's marriage to Ennis, we watch her environment become chaotic and dirty. Ennis comes in from work and finds Alma struggling to cook, and simultaneously to clean and care for the children, who are unwell. She asks Ennis to "wipe Alma Jr.'s nose.” As she does says this, her own face is grimy, as it often will be from this point forward: with sweat, cooking grease, or tear tracks.

Domestic dirt in Ang Lee's film does not connote Ennis's queerness, but Alma's unhappiness. She asks to move to town, promising that if they do, she will "fix it up real nice." Ennis responds that she could, "fix this place up real nice, if you wanted to." She doesn't, though: Alma has neither the capacity nor the desire to invest in "fixing up" the 
little out-of-town farm. At this point she still believes that if they relocate closer to town, and the society that she craves, she will be able to impose cleanliness and order, in accordance with the role of the ideal wife - which, on her wedding day, we saw her potential to become. Of course, this doesn't happen. In the apartment in Riverton, they live above a laundrette. It is a stretch to read the laundry as an intentionally ironic source of a new kind of dirt in Alma's life, but it is a pollutant nevertheless. The chaos of parents who both work, with two small children, now in a smaller, if brighter, space, is exacerbated particularly on film by the hum of the laundrette underlying domestic exchanges. Ennis also actively undermines Alma's autonomy and minimises her importance, by insisting that she should be able to take the children from him when she is at work in the store, because his work has to take precedence. He does not even take the time to properly encounter her protests: he simply overrides her, his larger body passing the burden of the children over to her smaller one. In this scene, too, Alma is left with a literal mess to contend with: Alma Jr. knocks over a jar of sweets, that spill around her mother's feet like marbles. The dirt of the domestic sphere spills over into Alma's professional life, and she has to explain her situation to her employer: the scene carries the sense that her life is contaminated by Ennis's presence in it. Proulx has said that "the story isn't about Jack and Ennis. It's about homophobia, it's about a social situation; it's about a place and a particular mindset and morality" (Cox, 2009). It's through Alma's relationship to dirt that this hostility to queer people, and the absence of a language to express it in, are embodied for a contemporary cinema audience. Alma's marriage to Ennis is charaterised by dirt and noise: everyday pollutants that are miraculously invisible from so many constructions of the domestic sphere. Once Alma has moved beyond the dirt and chaos of her first marriage, she becomes able to name and attack it: the dirt that almost swallowed her whole, she now sees, was the by-product of Ennis's queerness. "Jack Nasty," she spits, indicating her understanding of what was amiss in their 
home. By portraying Alma as struggling to live in dirty and polluted spaces, Ang Lee and Michelle Williams create a compelling case for Alma's anger: she should never have had to live the way she did. By taking subjective control of queer dirt away from the queer characters, however, the film alters the role of dirt in the short story fundamentally. Dirt remains a straight construction of queer sexuality, and a contaminant in Alma's life.

The representation of Alma Beers in Ang Lee's Brokeback Mountain uses the same techniques employed in Mudbound, to create empathy with the beautiful white woman in difficult circumstances. Both films, which also have a hyper-focus on specifically American rurality, carry traces of frontier mythology in their use of dirt as a mode for creating heroic characters. In Mudbound, however, the composition employs the male gaze in a comparable fashion to B.M. Bower's Lonesome Land, and so the dirt on Laura's body is only ever a means of objectifying her: asking the audience to look at her, and to enact a pre-existing methodology for reading the dirty white female body. Alma's relationship to dirt in Brokeback Mountain is part of a much more complex matrix, incorporating analysis of American society, and exploring dynamics of gender, sexuality and class in the modern period.

What is lost, in this, is some of the symbolism of the mountain itself in Brokeback Mountain. For Proulx, the mountain is a construction of the Garden of Eden: an Eden that is dirty, and queer, and morally good. In Ang Lee's film, dirt is made tangible to the cinema audience through Alma's disgust: an emotion that is never expressed by the two men on the mountain. Therefore, the critical potential for dirt to suggest a new way of being, to "matter" in the way that Christopher Schmidt articulates it, is minimised on-screen. Dirt - the simple, American fact of the dirty landscape - is a key trope across Western history. It is polyvalent, and complicated by intersections of gender, race, class and sexuality. This affective trope, we have seen here, is at its least compelling when it is simple. Landscape, class, American 
nature, poverty, sex, secrecy and shame can all be communicated through this single image: and the critical potential of the Western is at its sharpest when the polyphony is permitted to remain.

\section{Works Cited}

Bower, B.M.: Lonesome Land (2015 [c. 1911-12]). Irvine, CA: xist Publishing.

Cairns, Kate (2013): "Youth, Dirt, and the Spatialization of Subjectivity: An Intersectional Approach to White Rural Imaginaries." The Canadian Journal of Sociology/ Cahiers canadiens de sociologie, Vol. 38, No. 4, Park/ Santos special issue, 623-646.

Carter, Matthew (2014): Myth of the Western: New Perspectives on Hollywood's Frontier Narrative. Edinburgh: Edinburgh University Press.

Cather, Willa (2008 [1918]): My Ántonia. Oxford: Oxford University Press.

Cox, Christopher (2009): “The Art of Fiction no. 199.” The Paris Review, issue 188. $<$ https://www.theparisreview.org/interviews/5901/annie-proulx-the-art-of-fiction-no199-annie-proulx $>$.

Fiedler, Leslie A. (1968): The Return of the Vanishing American. London: Paladin.

Fluck, Winfried (2010): "Poor like Us: Poverty and Recognition in American Photography", Amerikastudien/ American Studies, Vol. 55, No.1, "Poverty and the Culturalization of Class", 63-93.

How The West Was Won (1962). Dir. John Ford, John, Henry Hathaway and George Marshall. Cinerama Releasing Corporation.

Handley, William R, ed. (2011): The Brokeback Book: From Story to Cultural Phenomenon Lincoln, NE and London: University of Nebraska Press.

Helm, Levon (2007): "Poor Old Dirt Farmer", on Dirt Farmer Compact Disk. Vanguard Records, track 2.

Healey, Kathleen (2019): “' The Mighty Meaning of the Scene': Feminine Landscapes and the Future of America in Margaret Fuller's Summer on the Lakes, in 1843". Humanities, 8 (1). 31. <https://doi.org/10.3390/h8010031.>

Jordan, Hillary (2008): Mudbound. New York, NY: Workman Publishing Company.

Lee, Ang (dir): Brokeback Mountain, 2005. Dir. Ang Lee. River Road Entertainment. 
Marubbio, M. Elise (2009): Killing the Indian Maiden: Images of Native American Women in Film. Lexington, KY: University Press of Kentucky.

Palmer, Phyllis (1989): Domesticity and Dirt: Domestic Servants in the United States, 19201945. Philadelphia, PA: Temple University Press.

Piacento, Ed (2014): "Hillary Jordan's Mudbound and the Neo-Segregation Narrative." The Mississippi Quarterly, vol. 67, No.2, 267-290.

Pontis, Charles (1968): True Grit. New York, NY: Simon and Schuster.

Prats, José Armando (2002): Invisible Natives:Myth and Identity in the American Western. Ithaca, NY and London.

Proulx, Annie (2004): Bad Dirt: More Wyoming Stories. New York, NY: Simon and Schuster.

Proulx, Annie (1999): Close Range: Wyoming Stories. London: Fourth Estate.

Mudbound, 2017. Dir. Dee Rees. Elevated Films and Joule Films.

Schmidt, Christopher (2009): “'Baby, I am the garbage': James Schuyler's Taste for Waste”, Iowa Journal of Cultural Studies, Vol. 10, Issue, 1, "Waste Issues", 57-73.

Springsteen, Bruce (1992): "Souls of the Departed" (song), on Lucky Town Compact Disk. Columbia Records, track 9.

Stacy, Jim ed. (2007): Reading Brokeback Mountain: Essays on the Story and Film (Jefferson: McFarland \& Company, Inc., 2007).

Shane, 1953. Dir. George Stevens. Paramount Pictures.

Turner, Frederick Jackson (1920 [1893]): The Frontier in American History [1893]. New York, NY: Henry Holt and Company. 